NBER WORKING PAPER SERIES

\title{
THE DARK SIDE OF OUTSIDE DIRECTORS: DO THEY QUIT WHEN THEY ARE MOST NEEDED?
}

\author{
Rüdiger Fahlenbrach \\ Angie Low \\ René M. Stulz \\ Working Paper 15917 \\ http://www.nber.org/papers/w15917
NATIONAL BUREAU OF ECONOMIC RESEARCH
1050 Massachusetts Avenue
Cambridge, MA 02138
April 2010

Fahlenbrach is Swiss Finance Institute Assistant Professor at Ecole Polytechnique Fédérale de Lausanne (EPFL). Low is Assistant Professor, Nanyang Business School, Nanyang Technological University, Singapore. Stulz is the Everett D. Reese Chair of Banking and Monetary Economics, Fisher College of Business, Ohio State University, and affiliated with NBER and ECGI. We thank Andy Kim and Helen Zhang for sharing with us their data on earnings restatements. Address correspondence to René M. Stulz, Fisher College of Business, The Ohio State University, 806 Fisher Hall, Columbus, OH 43210, stulz@cob.osu.edu. Fahlenbrach gratefully acknowledges financial support from the Swiss Finance Institute. The views expressed herein are those of the authors and do not necessarily reflect the views of the National Bureau of Economic Research.

NBER working papers are circulated for discussion and comment purposes. They have not been peerreviewed or been subject to the review by the NBER Board of Directors that accompanies official NBER publications.

(C) 2010 by Rüdiger Fahlenbrach, Angie Low, and René M. Stulz. All rights reserved. Short sections of text, not to exceed two paragraphs, may be quoted without explicit permission provided that full credit, including $\odot$ notice, is given to the source. 
The dark side of outside directors: Do they quit when they are most needed?

Rüdiger Fahlenbrach, Angie Low, and René M. Stulz

NBER Working Paper No. 15917

April 2010

JEL No. G30,G32,G34,G38,K22,M40

\begin{abstract}
$\underline{\text { ABSTRACT }}$
Outside directors have incentives to resign to protect their reputation or to avoid an increase in their workload when they anticipate that the firm on whose board they sit will perform poorly or disclose adverse news. We call these incentives the dark side of outside directors. We find strong support for the existence of this dark side. Following surprise director departures, affected firms have worse stock and operating performance, are more likely to suffer from an extreme negative return event, are more likely to restate earnings, and have a higher likelihood of being named in a federal class action securities fraud lawsuit.
\end{abstract}

Rüdiger Fahlenbrach

Ecole Polytechnique Fédérale de Lausanne

Odyssea 2.01 B, Station 5

1015 Lausanne

Switzerland

Ruediger.fahlenbrach@epfl.ch

Angie Low

Division of Banking and Finance

S3-B1A-30, Nanyang Avenue

Singapore 639798

AACLow@ntu.edu.sg
René M. Stulz

The Ohio State University

Fisher College of Business

806A Fisher Hall

2100 Neil Avenue

Columbus, OH 43210-1144

and NBER

stulz_1@cob.osu.edu 
Two of Ford's non-executive directors have resigned, reviving questions about the carmaker's stability. Sir John Bond, the chairman of Vodafone, and Jorma Ollila, the chairman of Nokia, will leave because each "had significant responsibilities within their own companies, and each has recently added new responsibilities in advising governmental entities during these difficult economic times," Ford said on Friday. Sunday Times, October 19, 2008

Corporate governance reforms following the corporate scandals of the turn of the century focused heavily on increasing the representation of outside directors on boards. Listing standards on U.S. exchanges were changed to require boards to have a majority of outside directors. Many countries have introduced requirements on the percentage of outside directors on boards as well as on the fraction of outside directors on the nominating committee, compensation committee, and audit committee (see IOSCO (2007)).

Although governance activists have been strong proponents of having more outside directors on boards, the theoretical and empirical academic literature has been more ambiguous. The theoretical literature points to costs and benefits of having more outside directors on the board. In particular, outside directors may have weaker incentives to expend effort, may have higher information acquisition costs, and may be more dependent on the CEO for their information (see, e.g., Fama and Jensen (1983), Harris and Raviv (2008), and Kumar and Sivaramakrishnan (2008)). ${ }^{1}$ Recent empirical papers on the structure and role of the board of directors (e.g., Boone et al. (2006), Coles et al. (2008), Duchin et al. (2010), and Linck et al. (2008)) have found evidence that firms structure their boards according to their monitoring and advising needs and take the costs and benefits of outside directors into account.

In this paper, we focus on a cost of board independence that has not received attention so far and demonstrate that it is economically significant. We show that outside directors have incentives to leave when they anticipate that the firm on whose board they sit will perform poorly and/or disclose adverse information. We call these incentives the dark side of outside directors. We find empirical evidence that

\footnotetext{
${ }^{1}$ It is therefore possible for firm performance to fall as the board becomes more independent. Though some papers find that firm performance increases with board independence (see, for instance, Black and Kim (2008), Aggarwal et al. (2009), and Dahya et al. (2008)), other papers find no relation between board independence and performance (see, for instance, Bhagat and Black (2002)).
} 
this dark side is economically significant and that outside directors are more likely to resign precisely when experienced outside directors are most needed.

Inside and outside directors face different trade-offs when deciding whether to stay on the board or resign. An inside director who resigns from the board most likely also has to resign from his job. Consequently, an inside director who has doubts about the firm's future or knows that the firm will reveal bad news may find that her best course of action is to stay on the board and work to improve the firm's performance. In contrast, an outside director in the same situation who does not resign faces the risk of experiencing a loss of reputation as an outside director when the bad news breaks. Such a loss of reputation may make it harder for the director to obtain other board seats and perhaps even to keep the seats she already has. Furthermore, the director would likely face an increase in her workload as the firm undergoes change and restructuring. Researchers have also shown that share price declines are followed by an increase in board meetings (see, e.g., Vafeas (1999)).

Researchers have shown that directors who sit on boards of firms in trouble see their reputations tarnished and face consequences in their future employability as directors. For example, Fich and Shivdasani (2007) find that following a financial fraud lawsuit in firms where they are directors, outside directors experience a decline in other board seats they hold. Srinivasan (2005) finds that outside directors of firms that restate earnings lose reputational capital. Gilson (1990) documents fewer board seats for outside directors after having served on boards of companies that experience financial distress, and Coles and Hoi (2003) and Harford (2003) show that outside directors have fewer new directorships if the board supports actions that are against shareholders' interests. Further, directors benefit from sitting on boards of better performing firms. For example, Yermack (2004) and Ferris, Jagannathan, and Pritchard (2003) find that directors who sit on the board of better performing firms are more likely to receive additional directorships in the future.

Outside directors are particularly valuable in situations where the firm's performance is troubled since at such times their independence enables them to assess objectively the performance of executives and make changes if they are appropriate (see, e.g., Hermalin and Weisbach (1988)). However, if outside 
directors have incentives to leave when they expect the firm's performance to become troubled, the usefulness of outside directors is lessened.

To investigate this dark side of outside directors, we first examine under what circumstances outside directors leave firms. Using Cox proportional hazard models, we find that directors are more likely to turn over if they are of retirement age (above 70 years old), if the firm had poor stock and accounting performance, if there is higher uncertainty, if the firm is larger, and if the CEO left during the prior year. This evidence is supportive of the view that outside directors are more likely to quit when the firm is performing poorly. However, these findings are not evidence on the reputation cost hypothesis since directors who resign because the firm has performed poorly presumably already have suffered the reputation loss. A more direct test of the dark side hypothesis is that directors are more likely to quit when they expect the firm to perform poorly and to disclose bad news, so that they can at least partly and possibly totally escape the reputation loss. A positive relation between director departures and future adverse events is consistent with directors quitting the firm to protect themselves.

To carry out these tests, we focus on unexpected or surprise director departures. Our director turnover regressions show that the most significant predictor of director turnover is directors being of retirement age. We would not expect future negative firm outcomes to be related to these expected director departures. Therefore, we focus on two measures of surprise director departures that are based on director characteristics. Most firms have mandatory director retirement ages, and a recent survey shows that the average mandatory retirement age is 71.4 years. ${ }^{2}$ We define our first measure of surprise outside director departures as any outside director turnover prior to the age of 70 . Our second measure is based on Cox proportional hazard regressions. We carefully specify a model of director turnover using additional director characteristics beyond director age, and define an unexpected director departure as a departure that happens although the survival function for serving one more year as a director is above $50 \%$.

\footnotetext{
${ }^{2}$ For example, the executive search firm Spencer Stuart reports in their 2009 Spencer Stuart Board Index publication (http://content.spencerstuart.com/sswebsite/pdf/lib/SSBI2009.pdf) that in 2004, 78\% of S\&P 500 firms had a mandatory retirement policy for outside directors. For these firms, $88 \%$ set the mandatory retirement age at 70 or 72 .
} 
Using these two measures, we find that unexpected director departures are strongly significant in our regressions predicting future adverse events. Following surprise director departures, affected firms have significantly worse stock and accounting performance, are significantly more likely to suffer from an extreme negative return event, are significantly more likely to restate earnings, and have a significantly higher likelihood of being named in a federal class action securities fraud lawsuit. These results are also economically significant. For example, the surprise departure of an outside director increases the probability of an earnings restatement by almost $20 \%$ and the probability of being named in a federal class action securities fraud lawsuit by 35\%. These results are consistent with directors leaving in anticipation of adverse events to protect their reputation or to avoid an increased workload. We also examine whether directors leave unexpectedly before poor merger decisions, but only find weak evidence.

One concern with our findings is that it could be that the director is not leaving in anticipation of the bad event but that instead it is the director's departure that causes the event because the firm loses a good adviser and/or monitor. This alternative explanation of our findings appears unlikely to be true because the period of wrongdoing precedes, for many of our tests, the announcement of the wrongdoing by several months. For example, for earnings restatements and litigations the actual misstatement or alleged fraud is likely to happen while the director is active on the board.

There are other reasons that directors could leave unexpectedly. For instance, a director could leave because of poor health, or she could leave because she feels powerless to prevent the board from taking what she perceives to be bad decisions. Finally, she could be fired. Directors leaving unexpectedly because of poor health would weaken our results. Directors who leave because they feel isolated leave when they are needed most. Directors who are fired would make our interpretation of the results incorrect. We examine whether the possibility of firings of directors is important enough to undermine our conclusions and find that it is not. First, Yermack (2004) writes that "For outside directors, the threat of replacement is more attenuated, since directors do not report to a higher authority that might fire them for poor performance." Second, we would expect that if directors are replaced for poor performance, it is 
much more likely to be in a situation where the CEO is replaced as well, but our results hold when we exclude all observations in which both inside directors and outside directors depart. Third, we support our results by looking at the subsample of directors that unexpectedly leave one firm, but accept a directorship in a firm from our sample in the two years surrounding their departure. Given that these directors have an active labor market, we consider it less likely that they were fired because they are bad outside directors. Our reasoning is corroborated by the fact that these outside directors with an active labor market leave poorly performing, smaller firms with more risk, and take on directorships in larger and more stable firms. When we repeat our analysis of future outcomes on this subsample of directors, we find that our results hold qualitatively and quantitatively except for the result on extreme negative stock returns.

There is limited study of the determinants of director turnover and career concerns of outside directors. Yermack (2004) finds that director turnover is related to bad firm performance, which is consistent with the evidence we report. Asthana and Balsam (2007) also find that directors are more likely to leave after poor performance, if the firm pays directors poorly, and if the firm is riskier. Brown and Maloney (1999) document that outside directors are more likely to depart prior to bad acquisitions. Agrawal and Chen (2009) examine 181 director resignations between 1994 and 2006 in which the director resigned amid dispute, filed a letter detailing his reasons for departures, and required that this letter be made public. They find a negative stock market reaction to the announcement of these disputes. In addition, affected firms have lower performance in the year following the dispute and are statistically significantly more likely to delist in the years following the disputed departure. Dewally and Peck (2010) analyze 52 announcements of director departures in which the directors publicly announce their resignation and compare these departures with 52 'quiet' director departures. They find that younger directors who are active professionals are more likely to announce their departures at poorly performing firms. Dewally and Peck (2010) interpret their evidence as consistent with these directors wanting to protect their reputation. Bar-Hava and Segal (2010) examine, using a sample of 900 director departures between 2004 and 2007, whether directors truthfully state the reason for departure. They classify the 
stated reasons for departure into four categories, one of which is "disagreement." They show that all categories of director departures are related to an increase in risk of litigation and conclude that not all directors truthfully tell why they have left the firm. In contrast to these studies, we are not focused on the reasons directors give for their resignations but instead explore whether unexpected resignations predict adverse performance and news for firms.

The remainder of the paper is structured as follows. Section 1 introduces the sample and databases we use. Section 2 examines the determinants of director departures. We analyze the performance of firms with outside director departures in Section 3, and examine additional outcome variables in Section 4. Section 5 concludes.

\section{Data sources and construction of the sample}

Our initial sample is formed by matching Standard and Poor's Compustat database with a database of directors obtained from Compact Disclosure. Compact Disclosure provides data on the board of directors of publicly listed U.S. firms. The raw sample consists of 738,908 director-firm-year observations. We follow each director through time from one proxy statement to the next. If a director is no longer listed in the subsequent proxy statement, he is defined as having left the board. Non-departing directors are those who continue to be listed in the subsequent proxy statement. Since we do not have the exact date of departure, we define the date of the subsequent proxy statement as the departure or event date. ${ }^{3,4}$ Our identification of departures depends on comparing adjacent proxy statements, therefore we delete observations for which we cannot find any subsequent proxy statements or for which the next proxy statement is more than 450 days away. We further require that the firm has asset data and a link for CRSP in the fiscal year end just prior to the event date. Firm-years with more than five directors departing are deleted as these likely suffer from a corporate control event. We further require that the director is

\footnotetext{
${ }^{3}$ We have checked 30 random director departures and in most cases the actual departure date is announced either a few months prior to the proxy date or in the proxy statement itself. Therefore, the departure date we have determined is the upper bound on the actual departure date.

${ }^{4}$ For brevity, we also refer to the subsequent proxy date as event date for non-departing directors.
} 
neither an inside director nor a former employee of the firm. The final sample consists of 332,327 outside director-firm-years (61,137 firm-proxy years) with 90,727 outside directorships, of which 30,421 end with a departure while the firm is in our sample. The sample covers 10,513 distinct firms, 64,105 distinct directors, and spans the period from 1989 to 2004.

We obtain accounting data from Compustat and stock return data from CRSP. Compact Disclosure is used to obtain information on director characteristics, board characteristics, director and officer ownership, and CEO turnover. All continuous variables are winsorized at the $1 \%$ level in both tails.

Data on accounting restatements between 1981 and 2006 come from two sources. For the period 1997 to 2006, the data come from the list of restatements compiled by the U.S. Government Accountability Office (GAO). Prior to that, the data on restatements are hand-collected from a news article search in Factiva. ${ }^{5}$ Data on firms that have been named in federal class action securities fraud lawsuits come from the Stanford Law School Securities Class Action Clearinghouse (securities.stanford.edu). The Clearinghouse maintains an index of filings since the passage of the Private Securities Litigation Reform Act of 1995. Finally, SDC Platinum is the data source for announcement dates and deal characteristics of mergers and acquisitions (M\&A) of sample firms.

\section{The determinants of director departures}

Table 1 describes summary statistics for our sample. Note that the summary statistics for director characteristics in Panel A are at the director-firm-year level and are separated by whether the director is departing or not. The firm characteristics in Panel B are at the firm-year level, and are split by whether or not there is at least one outside director departure in a firm year.

Panel A confirms the results of the aforementioned Spencer Stuart Director Study. The typical age for a director to step down is between 70 and 72 years. Interestingly, directors seem to be staying on

\footnotetext{
${ }^{5}$ We thank Andy Kim and Helen Zhang for providing us the data on restatements. The restatements data is used and described in Meschke and Kim (2010).
} 
beyond the age of 65 , the typical age for CEOs to step down from active duty (see, e.g., Warner et al. (1988), Huson et al. (2001), and Kaplan and Minton (2008)). The average tenure for a departing director is slightly less than that of a remaining director (3.95 years versus 4.07 years). Note that the director tenure is left censored since we measure director tenure from the date of the firm's first proxy statement in our database that she appears in. Using the Compact Disclosure dataset, we are able to determine whether the director is a CEO or non-CEO executive of another firm in our database at the time of the event date or departure date. Panel A shows that $3.84 \%$ of the departing directors are current CEOs of another firm while $6.06 \%$ of the non-departing directors are current CEOs. Similarly, departing directors are less likely to be current non-CEO executives than non-departing directors.

Panel B of Table 1 shows that there are more outside director departures in larger and older firms. Outside director departures are more frequent in firm-years where accounting and stock returns are poor. This fact mirrors results of studies of CEO turnover (e.g., Warner et al. (1988) and Kaplan and Minton (2008)) and is consistent with the finding of Yermack (2004) for director departures in his sample. Outside director departures are less frequent if the board is relatively small, the proportion of inside directors is relatively high, and director and officer ownership is high.

Table 2 shows results from Cox proportional hazard regressions of the tenure of each outside director until her turnover (the event) or until the firm leaves the sample (the censoring event). Column 1 shows proportional hazard regressions where we include director characteristics only as explanatory variables, and column 2 adds firm characteristics to the list of covariates. The table reports hazard ratios, i.e., exponentiated coefficients. The hazard ratios allow us to quantify the economic magnitude of the explanatory variable. For example, holding the other covariates constant, each additional board seat reduces the annual hazard of director turnover by 0.895 , i.e., $10.50 \% .^{6}$ By far the largest economic effect comes from the age indicator variable equal to one if the director is between 70 and 72 years old. Holding

\footnotetext{
${ }^{6}$ This negative relation between director turnover and board seats is consistent with results by Srinivasan (2005) and Asthana and Balsam (2007).
} 
the other covariates constant, being between 70 and 72 years old increases the annual hazard of director turnover by a factor of 2.398 , or $139.80 \%$.

Column 2 shows that poorer performance, both in terms of ROA and stock returns, increases the hazard of director turnover, which is consistent with the results reported by Yermack (2004). Higher return volatility increases the hazard of turnover. A large effect is observed whenever the CEO of the firm steps down in the previous year, which is consistent with results reported by Hermalin and Weisbach (1988) and Farrell and Whidbee (2000).

Our subsequent analysis requires a measure of unexpected turnover. One approach would be to collect disclosures of director departures and to evaluate the reasons given by directors for their departure. Such an approach does not seem appropriate for this study for at least three reasons. First, firms have only been required to disclose director departures systematically in 8-K reports (item 5.02 - Departure of Directors or Principal Officers) since August $2004 .^{7}$ If we use these disclosures, we would lose much of the time-series available to us. Second, Bar-Hava and Segal (2010) argue and provide evidence that outside directors have incentives not to disclose the true reasons for their departure in 8-K reports, which limits the usefulness of the disclosures. Third, using a newspaper article search to identify disclosures about director resignations would pose similar problems. In addition, many director departures are not publicly announced in newspapers, and even if they are announced, often no reason for departure is given.

Hence, we use our empirical analysis of director departures in Table 2 to construct measures of unexpected director departures. Since we are interested in departures unrelated to routine retirements, and given the very strong effect of the director age (70-72) indicator variable on the turnover hazard, our first measure of unexpected turnover is defined as any turnover that happens prior to the director turning 70 (Surprise departure measure (1)). While this measure is likely to be noisy, it has some appeal because of its simplicity. Our second measure is based on the Cox proportional hazard regression in Table 2, column 1 (Surprise departure measure (2)). For each director-firm-year observation, we calculate the survival

\footnotetext{
${ }^{7}$ Prior to 2004 , departures of directors were only disclosed in the 8-K report for departures due to disagreement. Disclosure was required only if the departing director explicitly requested that the nature of the disagreement with the firm be publicly disclosed. See Agrawal and Chen (2009) and Bar-Hava and Segal (2010) for details.
} 
function that measures the probability that the director will stay an additional year on the board of directors. If this function is higher than $50 \%$, but the director nevertheless steps down, we classify his departure as unexpected. Out of the 30,421 outside director departures, 21,396 departures are classified as surprise departures using our first measure while 24,460 departures are classified as surprise departures using the second measure. Conditional upon a departure, the correlation between the two measures of surprise departures is 0.63 .

\section{Outside director departures and future performance}

In this section, we analyze whether surprise departures of directors are related to future firm performance. We start with stock returns in section 3.1, followed by accounting performance in section 3.2, and a brief discussion of robustness checks in section 3.3.

\subsection{Stock returns}

We analyze stock returns in firms with and without outside director departures using a calendar time portfolio approach. Each month, we sort firms into two portfolios based on whether there is at least one outside director departure. Firms are added into the assigned portfolio in the month after the departure date or event date (when there is no departure) and held for 12 months or until the next proxy date occurs. Firm-years with inside director departures are excluded as inside director departures are likely to be associated with CEO and top executive turnovers. Since our sample covers many small firms, we calculate equal-weighted portfolio returns in excess of the 1-month risk-free interest rate. Table 3 shows the mean and median return for each portfolio as well as the return to a long-short portfolio in which the firms with outside director departures are bought and firms without outside director departures are sold. Panel A compares the return of the outside director departure portfolio (Portfolio 1) with the return of the no director departure portfolio (Portfolio 2). The portfolio that goes long the firms in which outside directors depart and short the firms where no outside directors depart produces a statistically significant average (median) monthly return of minus 18 basis points (minus 16 basis points). 
Panel B decomposes firm-years with outside director departures further into firm-years with expected and unexpected departures using surprise departure measure (1). We now form three portfolios. Portfolio 1S contains firm-years in which there is at least one unexpected outside director departure, while portfolio 1E contains firm-years in which all the departures are expected. Portfolio 2 is defined as before. Panel B of Table 3 shows that the negative stock return to the long-short portfolio of Panel A can be almost entirely attributed to the portfolio that is formed based on firm-years in which there are surprise director departures. The return to the long-short strategy "portfolio $1 \mathrm{~S}$ - portfolio 2" is minus 23 basis points, while the return to the long-short strategy "portfolio $1 \mathrm{E}$ - portfolio 2 " is an insignificant 4 basis points.

Panel C examines portfolio returns when the sample is split according to outside director surprise departure measure (2). The results are statistically and economically very close to the results of Panel B. The long-short portfolio that is long firms with surprise outside director departures generates excess returns of minus 20 basis points per month, while the average return of the long-short portfolio based on expected departures is an insignificant 2 basis point.

One possible explanation for the performance differences documented in Table 3 is that they are driven by differences in the characteristics of the two portfolios. Researchers have identified several equity characteristics that explain differences in realized returns. In Table 4, we account for these differences by estimating the four-factor model of Carhart (1997) and Fama and French (1993).

Panel A of Table 4 indicates that the long-short portfolio that goes long firms with outside director departures and short firms without those departures continues to underperform, even after the different characteristics have been taken into account. The estimated monthly alpha of the long-short portfolio is minus 18 basis points and is statistically significant at the $1 \%$ level.

Panel B, in which we use our surprise departure measure (1), shows that firms with surprise departures underperform firms without any outside director departures by 20 basis points. Interestingly, the factor loadings on the market, size, and value factors indicate that the long-short portfolio is tilted towards firms with higher market exposure, smaller firms, and firms with lower valuations. There is no 
statistically significant alpha generated by the long-short strategy that buys firms with expected director departures.

Panel C shows results for the long-short strategy using surprise departure measure (2). The longshort strategy that buys firms in which there are surprise outside director departures and sells firms with no outside director departures generates a statistically significant benchmark-adjusted monthly excess return of minus 17 basis points. The long-short strategy that uses expected director departures generates an insignificant excess return of minus 7 basis points.

Overall, the results on stock returns indicate that firms in which outside directors unexpectedly leave underperform firms with no outside director departures in the 12 months following the departure. Agrawal and Chen (2009) find similar results in their sample of 181 firms where directors leave because of publicly announced disputes with management. Our results show that the poor stock performance extends to a much broader sample of firms that experience director departures.

\subsection{Accounting performance}

We now turn to an analysis of accounting performance. Performance is measured using return on assets (ROA), defined as the ratio of operating income before depreciation over book value of assets. We calculate operating performance pre- and post-director turnover and examine the change in performance around the outside director departure. We measure operating performance before the appointment as the average over event years -3 to -1 , where year -1 is the fiscal year ending just prior to the event date. Performance after the director turnover is calculated as the average over event years +1 through +3 . The change in performance is the difference of the two averages. To control for industry, prior performance, and time effects, we calculate a performance and industry-adjusted ROA (see, e.g., Barber and Lyon (1996)). ${ }^{8}$ We require that the control firms do not have an outside director departure in the same year as

\footnotetext{
${ }^{8}$ Performance and industry-adjusted ROA is the difference between the unadjusted ROA and the ROA of a control firm. The control firm is the firm that is from the same two-digit SIC code and has ROA in year -1 that is within +/$10 \%$ of the firm's ROA.
} 
the departure firm. The ROA is adjusted before averages are taken. Similar to the stock returns analysis, we delete firm-years with inside director departures.

Table 5 shows the ROA surrounding the departures of outside directors. We again report our results in three panels - all departures of outside directors (Panel A), surprise departures using measure (1) (Panel B), and surprise departures using measure (2) (Panel C).

Consistent with the results of Table 2, we see from Table 5, Panel A that firms with outside director departures on average underperform industry- and performance-matched firms in the years prior to the outside director turnover, even though we have matched firms based on their performance in year 1. Panel A also shows that, on average, raw performance and adjusted performance deteriorate significantly after the director turnover. The results for changes in performance for the median firm are weaker though, with the performance and industry-adjusted change being indistinguishable from zero.

Panels B and C show results for the change in performance around surprise director departures. It is evident from these results that the average performance around surprise outside director departures deteriorates after the surprise departure. We can gauge the economic significance by relating the change in performance to the pre-turnover ROA. For example, for surprise departure measure (2), the change in performance is $-0.71 \%$. Relative to the average pre-turnover ROA of $6.27 \%$, this is a decrease in performance of $11.3 \%$.

\subsection{Robustness tests}

In the two analyses in sections 3.1 and 3.2, we exclude all firm-years with departures of at least one director who is a current or former employee of the firm (13,545 firm-years are deleted). Including departures of inside directors is likely to contaminate the results since they may be due to CEO turnover or other top executive departures from the firm. Prior studies have shown that operating performance improves around forced CEO turnover (Huson et al. (2004)) and that CEO turnover is likely to be preceded by poor stock performance (e.g., Warner et al. (1988)). Since director departures are more likely when the CEO leaves, we could be picking up effects of the CEO turnover instead if we were to include 
these firm-years. In unreported robustness checks, we show that the stock returns to long-short portfolios using surprise outside director departures remain quantitatively and qualitatively similar if we include the firm-years with inside director departures.

\section{Earnings restatements, litigation risk, mergers and acquisitions, and return skewness}

Our results on operating performance are consistent with a scenario in which the outside director anticipates deteriorating performance at the firm and leaves to protect her reputation or because she anticipates a significantly higher workload. We believe that this interpretation is the most plausible. However, we cannot exclude the possibility that the outside director departure has a causal effect on firm operating performance post departure. Under this hypothesis, the firm loses a talented outside director. Without her monitoring and advising capabilities, firm performance deteriorates post-director turnover.

In this section, we attempt to provide additional evidence that is supportive of the former reputational concern interpretation. We examine earnings restatements, litigation filings, and mergers and acquisitions in the year post-director turnover. These events have been shown to adversely affect the reputational capital of directors belonging to the affected firms. Furthermore, they have in common that they typically take some time from the initial wrongdoing/planning stage to the public announcement. This delay makes a causal interpretation from director departure to event implausible, since directors are likely to be still active in the firm at the time of the wrongdoing. For example, Fich and Shivdasani (2007) show summary statistics that the duration of the alleged violation in federal class action lawsuits is, on average, over one year (376 days), and that it takes another 100 days until a lawsuit is filed. Similarly, Agrawal and Cooper (2008) document that the average (median) number of days between the first day of the quarter restated and the restatement announcement date is over 700 days (500 days). This makes it unlikely that any incidence of earnings manipulation is due to the lack of control caused by the departure of a good outside director. In fact, the earnings that are being restated after the outside director leaves have typically been manipulated while the director was sitting on the board. However, what the director is 
likely to avoid is being associated with the bad press and shareholder ire following the announcement of the earnings restatement.

\subsection{Earnings restatements}

We start with a dataset of 3,397 announcements of earnings restatements between 1981 and 2006. Data on restatements for the period 1997 to 2006 comes from the list of restatements compiled by the U.S. Government Accountability Office (GAO). Prior to that, the data on restatements are hand-collected from a news article search in Factiva. We match this set of restating firms to our database and require that we have complete information on the firm around the restatement date. Figure 1 demonstrates how the dataset is being constructed. We check whether there is any outside director departure during period A and use this variable to predict the probability of a restatement in period $\mathrm{B}$. Therefore, the main variable of interest is an indicator variable which equals one if there is at least one outside director departure during period A. The control variables are taken as of the fiscal year ending just prior to Period $\mathrm{B}$. We use

control variables that have been identified as important in the prior literature (e.g., Larcker, Richardson, and Tuna (2007) and Srinivasan (2005)).

After requiring that there is information on director departures and control variables and that we can calculate the abnormal returns during the restatement announcement period, our sample contains 47,656 firm-years out of which 1,017 are affected by restatements. One third of the sample firm-years have at least one outside director departure.

Table 6 reports the results. The probability of a restatement is significantly positively associated with director departures in the prior year. The effect appears economically significant. The unconditional probability of a restatement is $2.13 \%(1,017 / 47,656)$. The coefficient of 0.003 hence signifies that the departure of an outside director increases the probability of a restatement by $14 \%$. The effect becomes stronger when we use either one of our measures of surprise outside director departures; the coefficient is 0.004 in columns 2 and 3. A surprise departure of an outside director therefore increases the probability of a restatement by $19 \%$. 
We carry out several robustness checks. Recent research on earnings restatements has suggested that not all restatements are material or revise earnings downward (e.g., Hennes et al. (2008)). We are interested in restatement events that are material so that they have the potential to adversely affect the director's reputation. Hence, we follow Gleason, Jenkins, and Johnson (2008), and focus on restatements where the announcement period cumulative abnormal return is less than $-1 \%$. We do not tabulate these results to conserve space. The announcement period abnormal returns are calculated using the market model, estimated over Day -280 to -61 , where Day 0 is the announcement date of the restatement. The abnormal returns are cumulated over Day -1 to Day +1 . There are 514 restatements with negative announcement returns of less than $-1 \%$ in a sample of 47,656 observations. ${ }^{9}$ We estimate logistic regressions similar to the ones in Table 6 , but where the dependent variable is equal to one if the firm experiences a restatement with abnormal announcement returns less than $-1 \%$ during the fiscal year, and zero otherwise. Firm-years with restatements that have abnormal announcement returns greater than $-1 \%$ are deleted. The coefficients on the three measures of outside director departures are all 0.002 and all are significant at least at the $5 \%$ level.

For about $42 \%$ of all restatements, the restatement announcement date is earlier than the departure date we have determined for the director. This is inevitable as we need to include the firm-years without restatements. Therefore, we cannot simply restrict ourselves to director departures that happen prior to the restatement announcement date since there are no such dates for firm-years without restatements. ${ }^{10}$ However, since we are predicting restatements using director departures, to alleviate concerns that the restatement may happen before the director leaves the firm, we have checked that the results are not materially affected by excluding such cases. It is important to note that the departure date

\footnotetext{
${ }^{9}$ The average (median) abnormal announcement returns to the 503 restatements with announcement returns greater than $-1 \%$ is $4.7 \%(2.4 \%)$. The average (median) abnormal announcement returns to the 514 restatements with announcement returns less than $-1 \%$ is $-10.7 \%(-6.2 \%)$.

${ }^{10} \mathrm{We}$ could also predict restatement announcements using departures that happen in earlier proxy statements. But since our departure date is already the upper bound, it is unlikely that directors would depart in anticipation of events that happen so far ahead.
} 
we have determined is the upper bound on the actual departure date, so always excluding these cases seems too conservative of a strategy.

\subsection{Shareholder litigation}

We use the database on federal class action securities fraud lawsuits provided by the Securities Class Action Clearinghouse of Stanford Law School and Cornerstone Research to identify instances of financial fraud. The database contains a comprehensive list of filings of federal class action securities fraud lawsuits filed after the Private Securities Litigation Reform Act of $1995 .{ }^{11}$ Therefore, the first lawsuit is in 1996. We match this database to our main database by ticker symbols. After requiring nonmissing information on director departures and control variables, the sample consists of 28,324 firm-year observations with 735 firm-years $(2.6 \%)$ of alleged securities fraud. The exact timing of the matching procedure follows the procedure outlined for earnings restatements in Figure 1.

A drawback to using class action lawsuits to identify financial fraud is that the class action securities fraud lawsuit database contains events where fraud is alleged, but is not actually proven. ${ }^{12}$ However, note that this fact biases us against uncovering evidence of directors leaving for reputational concerns prior to filings. One fact that is appealing for our purposes is that Black et al. (2006) convincingly demonstrate that out-of pocket liability risk from shareholder litigation for outside directors is actually extremely low. To the extent that directors worry about future litigation it therefore seems much more related to reputational rather than financial concerns.

Table 7 shows the results of logistic regressions in which the left-hand side variable is equal to one if in a given firm-year a federal class action securities fraud lawsuit was filed against the firm, and zero otherwise. The main variable of interest is an indicator variable indicating whether there is at least one outside director departure prior to the lawsuit filing. About one-third of the firm-years have a director

\footnotetext{
${ }^{11}$ For other research using federal class action securities fraud lawsuits see, e.g., Bajaj et al. (2003), Fich and Shivdasani (2007), and Black et al. (2006) and the references therein.

${ }^{12}$ For more details, the reader is referred to Fich and Shivdasani (2007) and Klausner (2010). Klausner (2010) empirically analyzes the differences between securities class action lawsuits and actual enforcement actions by the SEC.
} 
departure. The coefficient on outside director departures is highly statistically and economically significant. The departure of an outside director increases the probability of the filing of shareholder litigation by $0.5 \%$. The economic magnitude of this effect can be gauged by comparing this increase in probability relative to the base probability of filing. Relative to the unconditional sample mean probability of $2.6 \%$, the coefficient of $0.5 \%$ is equivalent to an increase of $19 \%$ in the probability of filing. Our finer measures that capture surprise departures of directors show even larger effects. The surprise departure of an outside director according to measure (1) increases the probability of filing by $0.8 / 2.6=31 \%$. The surprise departure of a director using measure (2) increases the probability of filing by $0.9 / 2.6=35 \%$.

Regarding the control variables, the incidence of class action securities fraud lawsuits is increasing in firm size, if stock and accounting returns were poor the prior year, and if the firm raised relatively more external financing in the prior year. These findings are consistent with research on shareholder lawsuits that has shown that firms are more likely to be sued if they are larger and had poorer returns in the prior year (see, for instance, Choi (2003)). Further, investors can sue firms that issued securities on various grounds.

For about $30 \%$ of our litigations, the filing date is earlier than the departure date we have determined for the director. In untabulated robustness tests, we deleted these cases since we are predicting litigation using director departures, so as to alleviate concerns that the litigation filing may happen before the director leaves the firm. Our results remain similar, with the coefficients being 0.003 (significant at the $5 \%$ level) for the first specification, and 0.005 (significant at the $1 \%$ level) for both the second and third specifications.

\subsection{Mergers and acquisitions}

We now examine whether the incidence of value-destroying mergers and acquisitions is higher after outside directors unexpectedly left and analyze both cumulative abnormal announcement returns and dollar changes around the event. Outside directors may choose to leave instead of trying to discipline managers when management is considering value-destroying acquisitions. We only include completed 
deals for domestic targets where the transaction value is at least one million dollars and at least $1 \%$ of the acquirer's market value prior to the announcement date. Deals where the effective date is more than 1,000 days away from the announcement date are also deleted. We calculate the cumulative abnormal returns of the acquirer over the event window $(-1$ day, +1 day), where day 0 is the announcement date. The abnormal returns are calculated based on a market model, where the parameters of the market model are estimated using data from days -280 to -61 . We also calculate the change in acquirer market capitalization from Day -2 to Day +1 in 2008 million dollars. The main variable of interest is an indicator which equals one if there is at least one outside director who departs in the 12 months prior to the announcement date. The control variables are similar to those used in prior studies on mergers and acquisitions (e.g., Moeller, Schlingemann, and Stulz (2005)). The final sample consists of 4,697 M\&A deals; $40 \%$ of the deals are associated with an outside director departure prior to the announcement date.

Table 8 shows the results. Panel A analyzes cumulative abnormal announcement returns while Panel B analyzes dollar changes. There is little evidence in Panel A of Table 8 that outside director departures are related to negative merger and acquisition announcement returns. The other control variables have coefficients that are consistent with the results of prior research (e.g., Moeller, Schlingemann, and Stulz (2005)).

Panel B shows the change in acquirer market value around the merger, and contains some evidence that surprise outside director departures, when measured with the more complex surprise departure measure (2), are associated with lower dollar changes of mergers and acquisitions. The surprise departure of an outside director in the year prior to the merger is associated with a dollar return that is approximately $\$ 80$ million lower.

\subsection{Skewness}

Outside directors are likely to worry in particular about actions that could result in large, negative shocks to firm value. We explicitly examined three events that could lead to such a destruction of firm value in sections 4.1 to 4.3 , but there could of course be other corporate or managerial actions that have 
the potential to harm shareholders and to damage the reputation of directors. We now take a more indirect approach and analyze whether extreme negative stock returns are more frequent in periods following the departure of outside directors. We define extreme negative returns as follows. A monthly return is defined as extreme if it is at least 3 standard deviations away from the past 24 months average. We start with the 61,137 firm-years in the director departure dataset. We define a firm-year to be an extreme negative return firm-year if at least one of the 12 monthly returns following the proxy date or director's departure is classified as extreme. We report results where we define returns using the logarithm of price changes, although results are quantitatively and qualitatively similar if we use simple returns instead.

We follow Chen, Hong, and Stein (2001) and control for the market capitalization, prior stock performance, stock volatility, and stock turnover. Specifically, we include as control variables the natural logarithm of market capitalization in the month of the proxy date or director's departure date (the event date), the average monthly return over the 12 months ending in the month of the event date, the average monthly standard deviation of daily stock returns over the 12 months ending in the month of the event date, and the average monthly share turnover over the prior 12 months. Turnover is defined as shares traded divided by shares outstanding. Since turnover data for Nasdaq is not comparable with that of NYSE and AMEX stocks, we define a turnover variable for the Nasdaq stocks and another turnover variable for the NYSE/AMEX stocks. ${ }^{13}$ The turnover variable for Nasdaq (NYSE/AMEX) stocks is set to zero for NYSE/AMEX (Nasdaq) stocks. After requiring non-missing information for control firms, our sample contains 60,460 firm-years, with $12.1 \%$ of those firm-years exhibiting extreme negative returns.

Table 9 shows the results. In column 1, we find that extreme negative stock returns are more likely to follow director departures. In columns 2 and 3 where we focus on surprise departures, the results appear much stronger. Surprise outside director departures are strongly related to extreme negative returns in the year following the director departure. The effect is economically meaningful. The surprise departure of at least one outside director increases the probability of a large negative return event by $0.9 \%$ $-1.1 \%$, or, relative to the sample mean of $12.1 \%$, by approximately $7.4 \%-9.1 \%$.

\footnotetext{
${ }^{13}$ For details, please see Atkins and Dyl (1997).
} 
The coefficients on the control variables suggest that larger firms, firms that experienced positive returns in the past, firms with lower stock return volatility, and Nasdaq firms with high turnover are more likely to experience an extreme negative stock return event. This is similar to Chen, Hong, and Stein (2001) who examine daily stock return skewness for a sample of NYSE/AMEX firms. They find that bigger firms, firms with higher stock returns in the past, and firms that experienced a surge in turnover are more crash-prone.

\subsection{Additional robustness tests}

In all tests of this section, we have used indicator variables equal to one if outside directors departed, and zero otherwise. We have neglected the concurrent departure of inside directors because the purpose of our study is an analysis of the reputational concerns of outside directors. We have verified that alternative treatments of firm-years in which both outside and inside directors depart does not materially affect our conclusions. First, we have re-estimated all regressions including an indicator variable equal to one if an inside director departed in a firm-year, and zero otherwise. ${ }^{14}$ The coefficients obtained on the outside director departure indicator variables from those regressions are quantitatively and qualitatively similar to the coefficients reported in Tables 6 to 9.

Second, we have re-estimated the regressions of Tables 6 to 9 by excluding firm-years in which at least one inside director departs to focus on years in which only outside directors leave. The results on shareholder litigation and skewness remain unaffected; results on earnings restatement become weaker (only the specification using surprise departure measure (2) is relevant) and the dollar change specifications on mergers and acquisitions become much stronger (all three director departure measures become relevant and the dollar change becomes more negative).

\footnotetext{
${ }^{14}$ Out of 39,711 firm-years without any outside director departures, 7,844 (19.6\%) firm-years have at least one inside director departure. In contrast, out of 21,426 firm-years with at least one outside director departures, 5,701 (26.61\%) have at least one inside director departure. The correlation between an indicator variable for outside director departure and inside director departure is $7.9 \%$. Similar numbers are obtained if we examine the surprise departure measures for outside directors.
} 
One concern regarding the interpretation of our results is that directors may not voluntarily leave the firm to protect their reputation, but are fired from the board. As explained in the introduction, we believe that this interpretation is unlikely. Nevertheless, we support our results by looking at the subsample of directors that unexpectedly leave one firm, but add a new board seat from a different firm in our sample in the same year. There are approximately 1,500 such outside director departures from 1,400 firm-years. Given that these directors have an active labor market, we consider it less likely that they were fired as outside directors because they were bad directors. Our reasoning is corroborated by (unreported) comparisons of the characteristics of firms that the outside directors drop and those that the directors add. Outside directors tend to trade up, that is they leave boards of poorly performing, smaller firms with more risk and take on board seats in larger and more stable firms. We have re-estimated all regressions reported in Tables 6 through 9 by substituting our outside director surprise departure variables with indicator variables for surprise outside director departures of directors with an active labor market. The results we report in Tables 6, 7, and 8 hold qualitatively and quantitatively using this smaller sample of surprise outside director departures with an active labor market. The results in Table 9 hold qualitatively, but become statistically insignificant.

\section{Conclusion}

In this paper, we show that there is a dark side to outside directors. Outside directors have incentives to quit to protect their reputation or to avoid increases in their workload when the firm on whose board they sit is likely to experience a tough time either because of poor performance or because of disclosure of adverse actions. Our evidence shows that following surprise outside director departures, affected firms have worse stock performance, worse accounting performance, a greater likelihood of an extreme negative return, a greater likelihood of a restatement, and a greater likelihood of being sued by their shareholders. These results provide further evidence that increasing board independence has costs as well as benefits. Further research should investigate whether different types of outside directors are more prone to resigning to protect their reputation and whether the capital markets react differently to the 
appointment of such directors. Another useful topic of research would be to analyze the impact of different types of compensation schemes on directors' incentives to quit to protect their reputation. 


\section{References}

Aggarwal, Reena, Isil Erel, René M. Stulz, and Rohan Williamson, 2009, Differences in governance practices between U.S. and foreign firms: Measurement, causes, and consequences, Review of Financial Studies 22, 3131-3169.

Agrawal, Anup, and Tommy Cooper, 2008, Insider trading before accounting scandals, Working Paper, University of Alabama.

Agrawal, Anup, and Mark A. Chen, 2009, Boardroom brawls: An empirical analysis of disputes involving directors, Working Paper, University of Alabama.

Asthana, Sharad, and Steven Balsam, 2007, Determinants of outside director turnover, Working Paper, University of Texas at San Antonio.

Atkins, Allen B., and Edward A. Dyl, 1997, Market structure and reported trading volume: NASDAQ versus the NYSE, Journal of Financial Research 20, 291-304.

Bajaj, Mukesh, Sumon C. Mazumdar, and Atulya Sarin, 2003, Securities class action settlements: An empirical analysis, Santa Clara Law Review 43, 1001-1033.

Bar-Hava, Keren, and Dan Segal, 2010, Do outside directors tell the truth, the whole truth, and nothing but the truth when they resign?, Working Paper, Interdisciplinary Center Herzliya.

Barber, Brad M., and John D. Lyon, 1996, Detecting abnormal operating performance: The empirical power and specification of test statistics, Journal of Financial Economics 41, 359-399.

Bhagat, Sanjai, and Bernard S. Black, 2002, The non-correlation between board independence and longterm firm performance, Journal of Corporation Law 27, 231-274.

Black, Bernard S., Brian R. Cheffins, and Michael Klausner, 2006, Outside director liability, Stanford Law Review 58, 1055-1159.

Black, Bernard S., and Woochan Kim, 2008, The effect of board structure on firm value: A multiple identification strategy approach using Korean data, Working Paper, University of Texas at Austin.

Boone, Audra L., Laura Casares Field, Jonathan M. Karpoff, and Charu G. Raheja, 2006, The determinants of corporate board size and composition: An empirical analysis, Journal of Financial Economics 85, 66-101.

Brown, William O., and Michael T. Maloney, 1999, Exit, voice, and the role of corporate directors: Evidence from acquisition performance, Working Paper, Claremont McKenna College.

Carhart, Mark, 1997, On persistence in mutual fund performance, Journal of Finance 52, 57-82.

Chen, Joseph, Harrison Hong, and Jeremy C. Stein, 2001, Forecasting crashes: Trading volume, past returns, and conditional skewness in stock prices, Journal of Financial Economics 61, 345-381.

Choi, Stephen J., 2003, The evidence on securities class actions, Vanderbilt Law Review 56, 1466-1525.

Coles, Jeffrey L, and Chun-Keung Hoi, 2003, New Evidence on the market for directors: Board membership and Pennsylvania Senate Bill 1310, Journal of Finance 58, 197-230.

Coles, Jeffrey L., Daniel Naveen, and Lalitha Naveen, 2008, Boards: Does one size fit all?, Journal of Financial Economics 87, 329-356.

Dahya, Jay, Orlin Dimitrov, and John J. McConnell, 2008, Dominant shareholders, corporate boards, and corporate value: A cross-country analysis, Journal of Financial Economics 87, 73-100.

Dewally, Michaël, and Sarah W. Peck, 2010, Upheaval in the boardroom: Outside director public resignations, motivations, and consequences, Journal of Corporate Finance 16, 38-52. 
Duchin, Ran, John G. Matsusaka, and Oguzhan Ozbas, 2010, When are outside directors effective?, Journal of Financial Economics, forthcoming.

Fama, Eugene F., and Kenneth R. French, 1993, Common risk factors in the returns on stocks and bonds, Journal of Financial Economics 33, 3-56.

Fama, Eugene F., and Michael C. Jensen, 1983, Separation of ownership and control, Journal of Law and Economics 26, 301-325.

Farrell, Kathleen A., and David A. Whidbee, 2000, The consequences of forced CEO succession for outside directors, Journal of Business 73, 597-627.

Ferris, Stephen P., Murali Jagannathan, and Adam C. Pritchard, 2003, Too busy to mind the business? Monitoring by directors with multiple board appointments, Journal of Finance 58, 1087-1111.

Fich, Eliezer M., and Anil Shivdasani, 2007, Financial fraud, director reputation, and shareholder wealth, Journal of Financial Economics 86, 306-336.

Gilson, Stuart C., 1990, Bankruptcy, boards, banks, and blockholders: Evidence on changes in corporate ownership and control when firms default, Journal of Financial Economics 27, 355-387.

Gleason, Cristi A., Nicole Thorne Jenkins, and W. Bruce Johnson, 2008, The contagion effects of accounting restatements, Accounting Review 83, 83-110.

Harford, Jarrad, 2003, Takeover bids and target directors' incentives: The impact of a bid on directors' wealth and board seats, Journal of Financial Economics 69, 51-83.

Harris, Milton, and Artur Raviv, 2008, A theory of board control and size, Review of Financial Studies 21, 1797-1832.

Hennes, Karen M., Andrew J. Leone, and Brian P. Miller, 2008, The importance of distinguishing errors from irregularities in restatement research: The case of restatements and CEO/CFO turnover, Accounting Review 83, 1487-1519.

Hermalin, Benjamin E. and Michael S. Weisbach, 1988. The determinants of board composition, RAND Journal of Economics 19, 589-606.

Huson, Mark R., Paul H. Malatesta, and Robert Parrino, 2004, Managerial succession and firm performance, Journal of Financial Economics 74, 237-275.

Huson, Mark R., Robert Parrino, and Laura T. Starks, 2001, Internal monitoring mechanisms and CEO turnover: A long-term perspective, Journal of Finance 56, 2265-2297.

International Organization of Securities Commissions (IOSCO), 2007, Board independence of listed companies, final report.

Kaplan, Steven N., and Bernadette Minton, 2008, How has CEO turnover changed?, Working Paper, Ohio State University.

Klausner, Michael, 2010, Are securities class actions "supplemental" to SEC enforcement? An empirical analysis, Working Paper, Stanford University.

Kumar, Praveen, and K. Sivaramakrishnan, 2008, Who monitors the monitor? The effect of board independence on executive compensation and firm value, Review of Financial Studies 21, 1371-1401.

Larcker, David F., Scott A. Richardson, and Irem Tuna, 2007, Corporate governance, accounting outcomes, and organizational performance, Accounting Review 82, 963-1008.

Linck, James S., Jeffry M. Netter, and Tina Yang, 2008, The determinants of board structure, Journal of Financial Economics 87, 308-328. 
Meschke, Felix, and Andy (Young Han) Kim, 2010, CEO interviews on CNBC, Working Paper, University of Minnesota.

Moeller, Sara B., Frederik P. Schlingemann, and René M. Stulz, 2005, Wealth destruction on a massive scale? A study of acquiring-firm returns in the recent merger wave, Journal of Finance 60, 757-782.

Srinivasan, Suraj, 2005, Consequences of financial reporting failure for outside directors: Evidence from accounting restatements and audit committee members, Journal of Accounting Research 43, 291-334.

Vafeas, Nikos, 1999, Board meeting frequency and firm performance, Journal of Financial Economics 53, 113-142.

Warner, Jerold B., Ross L. Watts, and Karen H. Wruck, 1988, Stock prices and top management changes, Journal of Financial Economics 20, 461-492.

Yermack, David, 2004, Remuneration, retention, and reputation incentives for outside directors, Journal of Finance 59, 2281-2308. 
Figure 1: Sample construction for tests of earnings restatements and director departures

Period B:

Did restatement happen during the fiscal year?

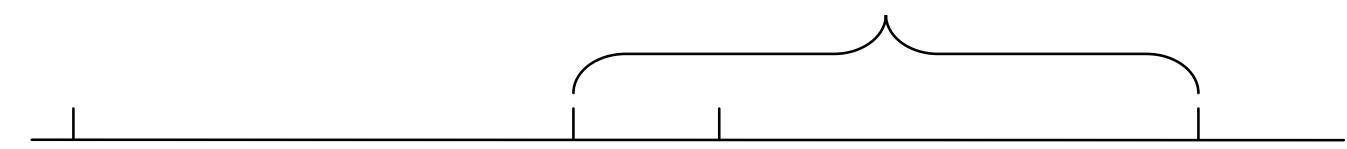

Last proxy
statement that
mentions
director

Did outside director leave during this period? 


\section{Table 1. Summary statistics}

The sample consists of 332,327 outside director-firm-years (61,137 firm-years) in publicly listed U.S. firms. Only outside directors are included; directors who are current and former employees of the firm are excluded. Panel A shows director characteristics, split by whether the director departed in any given year or not. The statistics in Panel $\mathrm{A}$ are at the director-firm-year level. Panel B shows firm characteristics, split by whether at least one outside director departed in a given firm-year. The statistics in Panel B are at the firm-year level. Accounting data is from Compustat, stock return data from CRSP, and data on director characteristics and governance is from Compact Disclosure. The accounting data is taken from Year -1 , where Year -1 is defined as the fiscal year ending just prior to the event date. Stock returns are buy-and-hold returns over the fiscal year ending just prior to the event date. Return volatility is the standard deviation of daily returns over the fiscal year ending just prior to the event date. The corporate governance data is taken as of the proxy statement prior to the event date. Dollar values are expressed in 2008 million dollars. Two-sample t-tests (Wilcoxon-Mann-Whitney tests) are conducted to test whether the means (medians) of departure years are significantly different from non-departure years. Statistical significance at the $1 \%$, $5 \%$, and $10 \%$ level is indicated by $* * *, * *$, and $*$, respectively.

\section{$\underline{\text { Panel A: Director characteristics }}$}

\begin{tabular}{|c|c|c|c|c|}
\hline & \multicolumn{2}{|c|}{$\begin{array}{l}\text { Non-departing directors } \\
\qquad(\mathrm{N}=301,906)\end{array}$} & \multicolumn{2}{|c|}{$\begin{array}{l}\text { Departing directors } \\
\qquad(\mathrm{N}=30,421)\end{array}$} \\
\hline & Mean & Median & Mean & Median \\
\hline Age indicator (64-66) (\%) & 11.60 & & $7.42 * * *$ & \\
\hline Age indicator (67-69) (\%) & 10.28 & & $8.16^{* * * *}$ & \\
\hline Age indicator (70-72) $(\%)$ & 6.08 & & $15.59 * * *$ & \\
\hline Age indicator (above 72) (\%) & 6.91 & & $13.12 * * *$ & \\
\hline Tenure (years) & 4.07 & 3.01 & $3.95 * * *$ & $2.99 * * *$ \\
\hline Current CEO (\%) & 6.06 & & $3.84 * * *$ & \\
\hline Former CEO (\%) & 7.57 & & $7.97 * *$ & \\
\hline Current executive (\%) & 5.22 & & $3.47 * * *$ & \\
\hline Former executive (\%) & 10.08 & & $9.26 * * *$ & \\
\hline No. of other directorships & 0.82 & 0.00 & $0.60 * * *$ & $0.00 * * *$ \\
\hline \multicolumn{5}{|l|}{$\underline{\text { Panel B: Firm characteristics }}$} \\
\hline & \multicolumn{2}{|c|}{$\begin{array}{l}\text { Non-departure years } \\
\qquad(\mathrm{N}=39,711)\end{array}$} & \multicolumn{2}{|c|}{$\begin{array}{l}\text { Departure years } \\
(\mathrm{N}=21,426)\end{array}$} \\
\hline & Mean & Median & Mean & Median \\
\hline Book assets & 1986.53 & 209.76 & $3918.24 * * *$ & $347.02 * * *$ \\
\hline Market cap & 1333.29 & 158.22 & $2126.33 * * *$ & $231.16 * * *$ \\
\hline Sales & 1196.87 & 178.00 & $2025.71 * * *$ & $256.48 * * *$ \\
\hline Firm age (years) & 15.93 & 10.00 & $18.22 * * *$ & $11.00 * * *$ \\
\hline Return on assets (ROA) (\%) & 8.58 & 11.42 & $5.15^{* * *}$ & $9.42 * * *$ \\
\hline Stock return $(\%)$ & 20.24 & 7.62 & $14.90 * * *$ & $4.49 * * *$ \\
\hline Return volatility (\%) & 3.82 & 3.31 & 3.84 & $3.20 * * *$ \\
\hline Board size & 7.68 & 7.00 & $9.36 * * *$ & $9.00 * * *$ \\
\hline Proportion of inside directors (\%) & 32.79 & 28.57 & $25.75 * * *$ & $22.22 * * *$ \\
\hline D\&O ownership (\%) & 24.73 & 18.82 & $20.24 * * *$ & $13.20 * * *$ \\
\hline
\end{tabular}




\section{Table 2. Cox proportional hazard regressions of director turnover}

The table reports results from a Cox proportional hazard model. The sample consists of 332,327 outside directorfirm-years, which track 90,727 directorships. Only outside directors are included; directors who are current and former employees of the firm are excluded. The time variable is director tenure in years until turnover (the event) or until the firm quits the sample. The status or event variable is outside director turnover. Of the 90,727 directors, 30,421 directors depart during our sample (experience the event); all other outside director tenures are treated as right-censored in the regressions. The accounting data are taken from year -1 , where year -1 is defined as the fiscal year ending just prior to the date the time variable is measured. Stock returns are buy-and-hold returns over year -1 . Return volatility is the standard deviation of daily returns over year -1 . The corporate governance data are taken as of the proxy statement prior to the date the time variable is measured. Age indicator variables are indicator variables equal to one if the director age falls within the specified range, and zero otherwise. CEO left indicator is an indicator variable equal to one if the CEO turned over during the past 12 months. The table reports hazard ratios (exponentiated coefficients). Standard errors are clustered at the firm level. Z-statistics are reported in parentheses. Statistical significance at the $1 \%, 5 \%$, and $10 \%$ level is indicated by ***,**, and *, respectively. 


\begin{tabular}{|c|c|c|}
\hline & $(1)$ & $(2)$ \\
\hline No. of other directorships & $\begin{array}{l}0.895^{* * *} \\
(-18.66)\end{array}$ & $\begin{array}{l}0.901 \text { *** } \\
(-16.27)\end{array}$ \\
\hline Age indicator (64-66) & $\begin{array}{l}0.743^{* * * *} \\
(-13.30)\end{array}$ & $\begin{array}{l}0.771^{* * * *} \\
(-10.85)\end{array}$ \\
\hline Age indicator (67-69) & $\begin{array}{l}0.891 \text { *** } \\
(-5.38)\end{array}$ & $\begin{array}{l}0.933^{* *} \\
(-3.01)\end{array}$ \\
\hline Age indicator (70-72) & $\begin{array}{l}2.398^{* * * *} \\
(54.52)\end{array}$ & $\begin{array}{l}2.572 \text { *** } \\
(54.32)\end{array}$ \\
\hline Age indicator (above 72) & $\begin{array}{l}1.761^{* * * *} \\
(32.99)\end{array}$ & $\begin{array}{l}1.871^{* * * *} \\
(33.09)\end{array}$ \\
\hline Current CEO director & $\begin{array}{l}0.870 * * * \\
(-4.44)\end{array}$ & $\begin{array}{l}0.877 * * * \\
(-3.90)\end{array}$ \\
\hline Former CEO director & $\begin{array}{l}1.167 * * * \\
(7.18)\end{array}$ & $\begin{array}{l}1.121^{* * * *} \\
(4.95)\end{array}$ \\
\hline Current executive director & $\begin{array}{l}0.832 * * * \\
(-5.76)\end{array}$ & $\begin{array}{l}0.828^{* * * *} \\
-(5.55)\end{array}$ \\
\hline Former executive director & $\begin{array}{c}0.98 \\
(-1.03)\end{array}$ & $\begin{array}{l}0.915^{* * * *} \\
(-4.13)\end{array}$ \\
\hline Log (sales) & & $\begin{array}{l}1.035^{* * * *} \\
(7.94)\end{array}$ \\
\hline Log (firm age) & & $\begin{array}{l}0.826 \text { *** } \\
(-19.18)\end{array}$ \\
\hline Stock return & & $\begin{array}{l}0.958^{* * * *} \\
(-4.64)\end{array}$ \\
\hline Return on assets & & $\begin{array}{l}0.529 * * * \\
(-17.11)\end{array}$ \\
\hline Return volatility & & $\begin{array}{l}1.096^{* * * *} \\
(29.21)\end{array}$ \\
\hline CEO left indicator & & $\begin{array}{l}1.172 * * * \\
(8.52)\end{array}$ \\
\hline Board size & & $\begin{array}{l}1.02 * * * \\
(12.30)\end{array}$ \\
\hline Proportion of inside directors & & $\begin{array}{l}0.650 \text { *** } \\
(-8.56)\end{array}$ \\
\hline D\&O ownership (\%) & & $\begin{array}{l}0.998 * * * \\
(-4.72)\end{array}$ \\
\hline Number of subjects & 90,285 & 80,666 \\
\hline Number of turnovers & 30,013 & 26,121 \\
\hline Number of observations & 331,834 & 287,558 \\
\hline
\end{tabular}




\section{Table 3. Univariate analysis of portfolio returns}

The table shows an analysis of stock returns in excess of the risk-free interest rate for different portfolios formed based on outside director departures. The analysis is based on 61,137 firm-years in the director departure dataset. Firm-years are excluded if there is at least one departure of a director who is a current or former employee of the firm, which reduces the sample to 47,592 firm-years. In Panel A, firms are sorted into two portfolios based on whether there is at least one outside director departure or not and are held in the portfolio for the subsequent 12 months. Portfolio 1 consists of firms where at least one outside director departs, and Portfolio 2 contains firms where there are no outside director departures. In Panels B and $\mathrm{C}$, we split the portfolio of outside director departures into portfolio $1 \mathrm{~S}$, consisting of firms with at least one surprise director departure and portfolio 1E, consisting of firms where all director departures are expected. Panel B defines expected director departures as departures of directors age 70 and above and treats departures of directors age 69 and below as surprise departures. Panel $\mathrm{C}$ defines surprise director departures as departures in which the director survival function from the Cox proportional hazard model in Table 2, Column 1 is higher than 50\%, but the director nevertheless departs. The table shows the monthly equal-weighted portfolio excess returns, where the excess returns are calculated by subtracting from the equal-weighted portfolio returns the risk-free rate taken from the Fama-French monthly factor dataset. $t$ tests and signed rank tests are used to test whether the mean and median monthly returns are significantly different from zero. Statistical significance at the $1 \%, 5 \%$, and $10 \%$ level is indicated by $* * * * *$, and $*$, respectively.

\begin{tabular}{|c|c|c|c|c|}
\hline & \multicolumn{4}{|c|}{ Equally-weighted portfolio ret } \\
\hline & \multicolumn{2}{|c|}{ Mean } & \multicolumn{2}{|c|}{ Median } \\
\hline \multicolumn{5}{|l|}{ Panel A: Outside director departure } \\
\hline Outside dir depart (Portfolio $=1$ ) & 0.0077 & $* *$ & 0.0123 & $* * *$ \\
\hline No dir depart (Portfolio $=2)$ & 0.0095 & $* * *$ & 0.0148 & $* * *$ \\
\hline Portfolio 1 - Portfolio 2 & -0.0018 & $* * *$ & -0.0016 & $* * *$ \\
\hline \multicolumn{5}{|l|}{ Panel B: Outside director surprise departure (1) } \\
\hline Outside dir surprise depart $($ Portfolio $=1 \mathrm{~S})$ & 0.0072 & * & 0.0118 & $* *$ \\
\hline Outside dir expected depart $($ Portfolio $=1 \mathrm{E})$ & 0.0091 & $* * *$ & 0.0120 & $* * *$ \\
\hline No dir depart (Portfolio $=2)$ & 0.0095 & $* * *$ & 0.0148 & $* * *$ \\
\hline Portfolio $1 \mathrm{~S}$ - Portfolio 2 & -0.0023 & $* * *$ & -0.0023 & $* * *$ \\
\hline Portfolio 1E - Portfolio 2 & -0.0004 & & -0.0002 & \\
\hline \multicolumn{5}{|l|}{ Panel C: Outside director surprise departure (2) } \\
\hline Outside dir surprise depart $($ Portfolio $=1 \mathrm{~S})$ & 0.0075 & $* *$ & 0.0113 & $* *$ \\
\hline Outside dir expected depart $($ Portfolio $=1 \mathrm{E})$ & 0.0107 & $* * *$ & 0.0120 & $* * *$ \\
\hline No dir depart $($ Portfolio $=2)$ & 0.0095 & $* * *$ & 0.0148 & $* * *$ \\
\hline Portfolio 1S - Portfolio 2 & -0.0020 & $* * *$ & -0.0023 & $* * *$ \\
\hline Portfolio 1E - Portfolio 2 & -0.0002 & & -0.0013 & \\
\hline
\end{tabular}




\section{Table 4. Monthly performance attribution regressions}

The table shows results of calendar-time portfolio performance attribution regressions. The analysis is based on 61,137 firm-years in the director departure dataset. Firm-years are excluded if there is at least one departure of a director who is a current or former employee of the firm, which reduces the sample to 47,592 firm-years. In Panel A, firms are sorted into two portfolios based on whether there is at least one outside director departure or not and held in the portfolio for the subsequent 12 months. Portfolio 1 consists of firms where at least one outside director departs, and Portfolio 2 contains firms where there are no outside director departures. In Panels B and C, we split the portfolio of director departures into portfolio $1 \mathrm{~S}$ of surprise director departures and portfolio $1 \mathrm{E}$ of expected director departures. Panel B defines expected director departures as departures of directors age 70 and above and treats departures of directors age 69 and below as surprise departures. If in a given firm-year, there is both a surprise departure and an expected departure, we assign the firm-year to the surprise departure portfolio. Panel C defines surprise director departures as departures in which the one-year outside director survival function of the Cox proportional hazard model in Table 2, Column 1 is higher than 50\%, but the director nevertheless departs. The table reports coefficient estimates from regressions based on a four- factor performance attribution model for the equalweighted monthly excess returns of the various portfolios. The four factors are defined in Fama and French (1993) and Carhart (1997). The factors are the returns to zero-investment portfolios designed to capture market (MKTRF), size (SMB), book-to-market (HML), and momentum (UMD) effects, respectively. Standard errors are reported in italics. Statistical significance at the $1 \%, 5 \%$, and $10 \%$ level is indicated by ***, **, and *, respectively. 
Panel A: Outside director departure

$\begin{array}{crlrlrrrrrrr}\text { Outside dir depart } & 0.0020 & * & & 0.9542 & * * * & 0.6794 & * * * & 0.2978 & * * * & -0.2285 & * * * \\ \text { (Portfolio = 1) } & 0.0010 & & 0.0267 & & 0.0285 & & 0.0354 & & 0.0205 & \\ \text { No dir depart } & 0.0038 & * * * & 0.9049 & * * * & 0.7288 & * * * & 0.2894 & * * * & -0.1989 & * * * \\ \text { (Portfolio = 2) } & 0.0010 & & 0.0255 & & 0.0272 & & 0.0338 & & 0.0196 & \\ \text { Portfolio 1 - Portfolio 2 } & -0.0018 & * * * & 0.0493 & * * * & -0.0494 & * * * & 0.0084 & & -0.0295 & * * \\ & 0.0006 & & 0.0157 & & 0.0167 & & 0.0208 & & 0.0120 & \end{array}$

Panel B: Outside director surprise departure (1)

\begin{tabular}{|c|c|c|c|c|c|c|c|c|c|c|}
\hline \multirow{2}{*}{$\begin{array}{l}\text { Outside dir surprise depart } \\
\quad(\text { Portfolio }=1 \mathrm{~S})\end{array}$} & 0.0018 & & 0.9733 & $* * *$ & 0.7646 & $* * *$ & 0.2265 & $* * *$ & -0.2598 & $* * *$ \\
\hline & 0.0012 & & 0.0323 & & 0.0344 & & 0.0427 & & 0.0247 & \\
\hline \multirow{2}{*}{$\begin{array}{c}\text { Outside dir expected } \\
\text { depart (Portfolio = 1E) }\end{array}$} & 0.0026 & $* * *$ & 0.8878 & $* * *$ & 0.4470 & $* * *$ & 0.4669 & $* * *$ & -0.1316 & $* * *$ \\
\hline & 0.0010 & & 0.0268 & & 0.0286 & & 0.0355 & & 0.0206 & \\
\hline \multirow{2}{*}{$\begin{array}{l}\text { No dir depart } \\
(\text { Portfolio = 2) }\end{array}$} & 0.0038 & $* * *$ & 0.9049 & $* * *$ & 0.7288 & $* * *$ & 0.2894 & $* * *$ & -0.1989 & $* * *$ \\
\hline & 0.0010 & & 0.0255 & & 0.0272 & & 0.0338 & & 0.0196 & \\
\hline \multirow{2}{*}{ Portfolio 1S - Portfolio 2} & -0.0020 & $* * *$ & 0.0684 & $* * *$ & 0.0359 & $*$ & -0.0628 & $* *$ & -0.0609 & $* * *$ \\
\hline & 0.0007 & & 0.0198 & & 0.0211 & & 0.0262 & & 0.0152 & \\
\hline \multirow{2}{*}{ Portfolio 1E - Portfolio 2} & -0.0011 & & -0.0171 & & -0.2818 & $* * *$ & 0.1775 & $* * *$ & 0.0673 & $* * *$ \\
\hline & 0.0010 & & 0.0277 & & 0.0295 & & 0.0367 & & 0.0213 & \\
\hline \multicolumn{11}{|c|}{ Panel C: Outside director surprise departure (2) } \\
\hline \multirow{2}{*}{$\begin{array}{l}\text { Outside dir surprise depart } \\
\quad(\text { Portfolio }=1 \mathrm{~S})\end{array}$} & 0.0018 & & 0.9713 & $* * *$ & 0.7480 & $* * *$ & 0.2480 & $* * *$ & -0.2517 & $* * *$ \\
\hline & 0.0012 & & 0.0330 & & 0.0346 & & 0.0429 & & 0.0245 & \\
\hline \multirow{2}{*}{$\begin{array}{c}\text { Outside dir expected } \\
\text { depart }(\text { Portfolio }=1 \mathrm{E})\end{array}$} & 0.0028 & & 0.8800 & $* * *$ & 0.4615 & $* * *$ & 0.4992 & $* * *$ & -0.1534 & $* * *$ \\
\hline & 0.0020 & & 0.0537 & & 0.0562 & & 0.0697 & & 0.0398 & \\
\hline \multirow{2}{*}{$\begin{array}{l}\text { No dir depart } \\
(\text { Portfolio = 2) }\end{array}$} & 0.0035 & $* * *$ & 0.9015 & $* * *$ & 0.7318 & $* * *$ & 0.2946 & $* * *$ & -0.2033 & $* * *$ \\
\hline & 0.0010 & & 0.0272 & & 0.0284 & & 0.0353 & & 0.0201 & \\
\hline \multirow{2}{*}{ Portfolio 1S - Portfolio 2} & -0.0017 & $* *$ & 0.0698 & $* * *$ & 0.0161 & & -0.0466 & $*$ & -0.0485 & $* * *$ \\
\hline & 0.0007 & & 0.0199 & & 0.0208 & & 0.0258 & & 0.0147 & \\
\hline \multirow{2}{*}{ Portfolio 1E - Portfolio 2} & -0.0007 & & -0.0215 & & -0.2703 & $* * *$ & 0.2046 & $* * *$ & 0.0498 & \\
\hline & 0.0020 & & 0.0541 & & 0.0566 & & 0.0702 & & 0.0400 & \\
\hline
\end{tabular}




\section{Table 5. Operating performance around director departures}

The table reports firm operating performance around director departures. The analysis is based on 61,137 firm-years in the director departure dataset. Firm-years are excluded if there is at least one departure of a director who is a current or former employee of the firm, resulting in 47,592 firm-years. Return on assets (ROA) is defined as the ratio of operating income before depreciation to book assets. Performance, industry-adjusted ROA is the difference between the unadjusted ROA and the ROA of a control firm. The control firm is the firm that is from the same twodigit SIC code and has ROA in year -1 that is within $+/-10 \%$ of the firm's ROA, where year -1 is the fiscal year end just prior to the director's departure date. We require that the control firms not have an outside director departure in year 0. ROA is averaged before and after the event. In Panels B and C, we split director departures into surprise director departures and expected director departures. Surprise departure (1) is defined as all outside director departures of directors age 69 and below. Surprise departure (2) is defined as all outside director departures in which the one-year outside director survival function from the Cox proportional hazard model in Table 2, Column 1 is higher than $50 \%$, but the director nevertheless departs. $t$-Tests and signed rank tests are used to determine whether the means and medians are significantly different from zero. Statistical significance at the $1 \%, 5 \%$, and $10 \%$ level is indicated by $* * *, * *$, and *, respectively.

\section{Panel A: All outside director departures}

\begin{tabular}{|c|c|c|c|c|}
\hline & Mean & & Mediar & \\
\hline & \multicolumn{4}{|c|}{$\underline{\mathrm{ROA}}$} \\
\hline Before $(-3,-1)$ & 0.0726 & $* * *$ & 0.1080 & $* * *$ \\
\hline After $(+1,+3)$ & 0.0650 & $* * *$ & 0.1000 & $* * *$ \\
\hline \multirow[t]{2}{*}{ Change } & -0.0075 & $* * *$ & -0.0031 & $* * *$ \\
\hline & \multicolumn{4}{|c|}{ Performance, industry-adjusted ROA } \\
\hline Before $(-3,-1)$ & -0.0033 & $* * *$ & 0.0003 & \\
\hline After $(+1,+3)$ & -0.0073 & $* * *$ & 0.0003 & \\
\hline Change & -0.0039 & $* * *$ & 0.0003 & \\
\hline
\end{tabular}

$\underline{\text { Panel B: Outside director surprise departures (1) }}$

\begin{tabular}{lcccc}
\hline & \multicolumn{1}{c}{ Mean } & \multicolumn{2}{c}{ Median } \\
\hline \multicolumn{4}{c}{$\underline{\text { ROA }}$} \\
Before $(-3,-1)$ & 0.0596 & $* * *$ & 0.1025 & $* * *$ \\
After $(+1,+3)$ & 0.0534 & $* * *$ & 0.0948 & $* * *$ \\
Change & -0.0062 & $* * *$ & -0.0031 & $* * *$ \\
& \multicolumn{5}{c}{} \\
& Performance, industry-adjusted ROA \\
Before $(-3,-1)$ & -0.0046 & $* * *$ & 0.0003 & \\
After $(+1,+3)$ & -0.0104 & $* * *$ & -0.0001 & $* * *$ \\
Change & -0.0058 & $* * *$ & 0.0002 & $*$ \\
& & & & \\
\hline
\end{tabular}


Panel C: Outside director surprise departures (2)

\begin{tabular}{lcccc}
\hline & \multicolumn{1}{c}{ Mean } & \multicolumn{2}{c}{ Median } \\
\hline \multicolumn{4}{c}{$\underline{\text { ROA }}$} \\
Before $(-3,-1)$ & 0.0627 & $* * *$ & 0.1017 & $* * *$ \\
After $(+1,+3)$ & 0.0556 & $* * *$ & 0.0937 & $* * *$ \\
Change & -0.0071 & $* * *$ & -0.0031 & $* * *$ \\
& \multicolumn{4}{c}{} \\
& \multicolumn{4}{c}{ Performance, industry-adjusted ROA } \\
Before $(-3,-1)$ & -0.0041 & $* * *$ & 0.0003 & \\
After $(+1,+3)$ & -0.0100 & $* * *$ & -0.0002 & $* * *$ \\
Change & -0.0060 & $* * *$ & -0.0001 & $* *$ \\
& & & & \\
\hline
\end{tabular}




\section{Table 6. Outside director departures and subsequent earnings restatements}

The table shows results from logistic regressions of a subsequent earnings restatement announcement following outside director departures. Announcement dates of restatements from 1997 onwards are from the list of restatements compiled by the U.S. Government Accountability Office (GAO). Prior to that, the data on restatements are hand-collected from a news article search in Factiva. The dependent variable is an indicator variable equal to one if there is a restatement announcement during the fiscal year, and zero otherwise. Outside dir depart indicator is equal to one if there is at least one outside director departure in the year prior to the fiscal year in which earnings are restated. Surprise outside director departure (1) is an indicator variable which equals one if there is at least one departure of an outside director age 69 and below. Surprise outside director departure (2) is an indicator variable which equals one if there is at least one departure of an outside director whose survival function from the Cox proportional hazard model in Table 2, Column 1 is higher than 50\%, but the director nevertheless departs. The accounting data is taken from the fiscal year end just prior to the restatement. Cash flow is equal to the sum of net income before extraordinary items and depreciation divided by book assets. External financing is equal to the sum of net equity financing and net debt financing divided by book assets. Cash acquisition is the ratio of cash spent on acquisitions to book assets. Standard errors clustered at the firm level are reported in italics. Intercepts are not reported. Marginal effects and their corresponding standard errors are provided. Statistical significance at the $1 \%$, $5 \%$, and $10 \%$ level is indicated by $* * *, * *$, and $*$, respectively.

\begin{tabular}{llll}
\hline & $(1)$ & $(2)$ & $(3)$ \\
\hline Outside dir depart indicator & $0.003^{* *}$ & & \\
& 0.001 & & \\
Outside dir surprise depart (1) & & $0.004^{* * *}$ & \\
& & 0.001 & \\
Outside dir surprise depart (2) & & & $0.004^{* * *}$ \\
& & & 0.001 \\
Board size & -0.000 & -0.000 & -0.000 \\
& 0.000 & 0.000 & 0.000 \\
Proportion of outside directors & 0.000 & -0.000 & -0.000 \\
& 0.003 & 0.003 & 0.003 \\
Log (Sales) & $0.004^{* * *}$ & $0.004^{* * *}$ & $0.004^{* * *}$ \\
& 0.000 & 0.000 & 0.000 \\
Stock return & 0.000 & 0.000 & 0.000 \\
& 0.001 & 0.001 & 0.001 \\
Cash flow & $-0.014 * * *$ & $-0.014^{* * *}$ & $-0.013^{* * *}$ \\
& 0.003 & 0.003 & 0.003 \\
External financing & 0.004 & 0.004 & 0.004 \\
& 0.002 & 0.002 & 0.002 \\
Cash acquisitions & $0.013^{* *}$ & $0.012^{* *}$ & $0.012^{* *}$ \\
& 0.006 & 0.006 & 0.006 \\
\hline Pseudo R-Sq & 0.07 & 0.07 & 0.07 \\
N & 47,656 & 47,656 & 47,651 \\
Year fixed effects & Yes & Yes & Yes \\
\hline
\end{tabular}




\section{Table 7. Outside director departures and subsequent federal class action securities fraud lawsuit filings}

The table shows results from logistic regressions of the filing of a federal class action securities fraud lawsuit following outside director departures. Data on firms that have been named in federal class action securities fraud lawsuits come from the Stanford Law School Securities Class Action Clearinghouse. The dependent variable is an indicator variable equal to one if there is a lawsuit filing during the fiscal year, and zero otherwise. Outside dir depart indicator is equal to one if there is at least one outside director departure in the year prior to the fiscal year in which the lawsuit is filed. Surprise outside director departure (1) is an indicator variable which equals one if there is at least one departure of an outside director age 69 and below. Surprise outside director departure (2) is an indicator variable which equals one if there is at least one departure of an outside director whose survival function from the Cox proportional hazard model in Table 2, Column 1 is higher than 50\%, but the director nevertheless departs. The accounting data is taken from the fiscal year end just prior to the lawsuit event. External financing is equal to the sum of net equity financing and net debt financing divided by book assets. Standard errors clustered at the firm level are reported in italics. Intercepts are not reported. Marginal effects and their corresponding standard errors are provided. Statistical significance at the $1 \%, 5 \%$, and $10 \%$ level is indicated by $* * *, * *$, and $*$, respectively.

\begin{tabular}{llll}
\hline & $(1)$ & $(2)$ & $(3)$ \\
\hline Outside dir depart indicator & $0.005^{* * *}$ & & \\
& 0.002 & & \\
Outside dir surprise depart (1) & & $0.008^{* * *}$ & \\
& & 0.002 & \\
Outside dir surprise depart (2) & & & $0.009^{* * *}$ \\
& & & 0.002 \\
Board size & $-0.002^{* * *}$ & $-0.002^{* * *}$ & $-0.002^{* * *}$ \\
& 0.000 & 0.000 & 0.000 \\
Proportion of outside directors & 0.006 & 0.005 & 0.005 \\
& 0.005 & 0.005 & 0.005 \\
Log (sales) & $0.006^{* * *}$ & $0.006^{* * *}$ & $0.006^{* * *}$ \\
& 0.001 & 0.001 & 0.000 \\
Stock return & $-0.003^{* *}$ & $-0.003^{* *}$ & $-0.003^{* *}$ \\
& 0.001 & 0.001 & 0.001 \\
ROA & $-0.009^{*}$ & $-0.009^{*}$ & $-0.008^{*}$ \\
& 0.005 & 0.005 & 0.005 \\
External financing & $0.031^{* * *}$ & $0.031^{* * *}$ & $0.031^{* * *}$ \\
& 0.003 & 0.003 & 0.003 \\
\hline Pseudo R-Sq & 0.06 & 0.06 & 0.06 \\
$\mathrm{~N}$ & 28,324 & 28,324 & 28,320 \\
Year fixed effects & Yes & Yes & Yes \\
\hline
\end{tabular}


Table 8. Outside director departures and subsequent merger and acquisition profitability

The table examines the profitability of mergers and acquisitions (M\&A) following outside director departures. The M\&A deals are from SDC Platinum. In Panel A, the dependent variable is the cumulative abnormal announcement return to M\&A activities of sample firms. The cumulative abnormal announcement returns are measured over the event window ( -1 day, +1 day), where day 0 is the announcement date. The abnormal returns are calculated from a market model, where the parameters of the market model are estimated using the CRSP equal-weighted market returns and data from days -280 to -61 . In Panel B, the dependent variable is the change in acquirer market capitalization from day -2 to day +1 , in millions of 2008 dollars. Outside dir depart indicator is equal to one if there is at least one outside director departure in the 12 months prior to the deal announcement date. Surprise outside director departure (1) is an indicator variable which equals one if there is at least one departure of an outside director age 69 and below. Surprise outside director departure (2) is an indicator variable which equals one if there is at least one departure of an outside director whose survival function from the Cox proportional hazard model in Table 2, Column 1 is higher than $50 \%$, but the director nevertheless departs. The accounting data are from the fiscal year end just prior to the announcement. Deal characteristics are from SDC Platinum. Robust standard errors are reported in italics. Statistical significance at the $1 \%, 5 \%$, and $10 \%$ level is indicated by ***, **, and *, respectively. 
$\underline{\text { Panel A: Cumulative abnormal announcement returns }}$

\begin{tabular}{|c|c|c|c|}
\hline & $(1)$ & $(2)$ & (3) \\
\hline \multirow[t]{2}{*}{ Outside dir depart indicator } & 0.002 & & \\
\hline & 0.003 & & \\
\hline \multirow[t]{2}{*}{ Outside dir surprise depart (1) } & & 0.005 & \\
\hline & & 0.003 & \\
\hline \multirow[t]{2}{*}{ Outside dir surprise depart (2) } & & & 0.004 \\
\hline & & & 0.003 \\
\hline \multirow[t]{2}{*}{ Board size } & 0.000 & 0.000 & 0.000 \\
\hline & 0.000 & 0.000 & 0.000 \\
\hline \multirow[t]{2}{*}{ Proportion of outside directors } & -0.011 & -0.011 & -0.011 \\
\hline & 0.008 & 0.008 & 0.008 \\
\hline \multirow[t]{2}{*}{ Log(assets) } & $-0.005 * * *$ & $-0.005 * * *$ & $-0.005 * * *$ \\
\hline & 0.001 & 0.001 & 0.001 \\
\hline \multirow[t]{2}{*}{ Book leverage } & -0.010 & -0.011 & -0.011 \\
\hline & 0.011 & 0.011 & 0.011 \\
\hline \multirow[t]{2}{*}{ Tobin's $Q$} & $-0.003 * * *$ & $-0.003 * * *$ & $-0.003 * * *$ \\
\hline & 0.001 & 0.001 & 0.001 \\
\hline \multirow[t]{2}{*}{ Private target indicator } & -0.000 & -0.000 & -0.000 \\
\hline & 0.005 & 0.005 & 0.005 \\
\hline \multirow[t]{2}{*}{ Public target indicator } & $-0.033 * * *$ & $-0.033 * * *$ & $-0.033 * * *$ \\
\hline & 0.005 & 0.005 & 0.005 \\
\hline \multirow[t]{2}{*}{ Same industry indicator } & -0.005 & -0.005 & -0.005 \\
\hline & 0.003 & 0.003 & 0.003 \\
\hline \multirow[t]{2}{*}{ Tender offer indicator } & $0.020 * * *$ & $0.020 * * *$ & $0.020 * * *$ \\
\hline & 0.005 & 0.005 & 0.005 \\
\hline \multirow[t]{2}{*}{ Hostile deal indicator } & -0.004 & -0.003 & -0.004 \\
\hline & 0.011 & 0.011 & 0.011 \\
\hline \multirow[t]{2}{*}{ Competed deal indicator } & 0.001 & 0.001 & 0.001 \\
\hline & 0.010 & 0.010 & 0.010 \\
\hline \multirow[t]{2}{*}{$100 \%$ cash payment indicator } & $0.012 * * *$ & $0.012 * * *$ & $0.012 * * *$ \\
\hline & 0.004 & 0.004 & 0.004 \\
\hline \multirow[t]{2}{*}{$100 \%$ stock payment indicator } & -0.002 & -0.002 & -0.002 \\
\hline & 0.004 & 0.004 & 0.004 \\
\hline \multirow[t]{2}{*}{ Cash flow / assets } & -0.021 & -0.020 & -0.020 \\
\hline & 0.016 & 0.016 & 0.016 \\
\hline \multirow[t]{2}{*}{ Transaction value / acq market value } & $0.017 * *$ & $0.017 * *$ & $0.017 * *$ \\
\hline & 0.007 & 0.007 & 0.007 \\
\hline $\mathrm{N}$ & 4,697 & 4,697 & 4,696 \\
\hline Adj R-Sq & 0.09 & 0.09 & 0.09 \\
\hline Year fixed effects & Yes & Yes & Yes \\
\hline Industry fixed effects & Yes & Yes & Yes \\
\hline
\end{tabular}


Panel B: Change in acquirer market capitalization

\begin{tabular}{|c|c|c|c|}
\hline & (1) & (2) & (3) \\
\hline Outside dir depart indicator & $\begin{array}{l}-35.019 \\
39.494\end{array}$ & & \\
\hline Outside dir surprise depart (1) & & $\begin{array}{l}-42.824 \\
44.285\end{array}$ & \\
\hline Outside dir surprise depart (2) & & & $\begin{array}{l}-79.874 * \\
46.777\end{array}$ \\
\hline Board size & $\begin{array}{l}-9.141 \\
6.886\end{array}$ & $\begin{array}{l}-9.224 \\
6.953\end{array}$ & $\begin{array}{l}-9.070 \\
6.885\end{array}$ \\
\hline Proportion of outside directors & $\begin{array}{l}-27.603 \\
79.002\end{array}$ & $\begin{array}{l}-28.138 \\
75.736\end{array}$ & $\begin{array}{l}-19.053 \\
79.695\end{array}$ \\
\hline Log(Assets) & $\begin{array}{l}-87.448^{* * * *} \\
20.022\end{array}$ & $\begin{array}{l}-87.992 * * * \\
20.170\end{array}$ & $\begin{array}{l}-88.340 * * * \\
20.238\end{array}$ \\
\hline Book leverage & $\begin{array}{l}141.566 \\
119.236\end{array}$ & $\begin{array}{l}143.253 \\
119.350\end{array}$ & $\begin{array}{l}145.762 \\
119.304\end{array}$ \\
\hline Tobin's $Q$ & $\begin{array}{l}-70.144 * * \\
32.331\end{array}$ & $\begin{array}{l}-69.954^{* * *} \\
32.257\end{array}$ & $\begin{array}{l}-70.162^{* * *} \\
32.254\end{array}$ \\
\hline Private target indicator & $\begin{array}{l}-38.491 \\
29.877\end{array}$ & $\begin{array}{l}-37.821 \\
29.940\end{array}$ & $\begin{array}{l}-37.581 \\
29.934\end{array}$ \\
\hline Public target indicator & $\begin{array}{l}-129.640 * * * \\
36.654\end{array}$ & $\begin{array}{l}-129.257 * * * \\
36.605\end{array}$ & $\begin{array}{l}-129.026^{* * * *} \\
36.635\end{array}$ \\
\hline Same industry indicator & $\begin{array}{l}50.934 \\
47.765\end{array}$ & $\begin{array}{l}50.950 \\
47.719\end{array}$ & $\begin{array}{l}50.376 \\
47.738\end{array}$ \\
\hline Tender offer indicator & $\begin{array}{l}160.419 * \\
86.868\end{array}$ & $\begin{array}{l}161.920^{*} \\
86.927\end{array}$ & $\begin{array}{l}160.894 * \\
86.918\end{array}$ \\
\hline Hostile deal indicator & $\begin{array}{l}-643.865 \\
525.805\end{array}$ & $\begin{array}{l}-648.332 \\
524.640\end{array}$ & $\begin{array}{l}-644.263 \\
525.022\end{array}$ \\
\hline Competed deal indicator & $\begin{array}{l}-140.741 \\
191.484\end{array}$ & $\begin{array}{l}-143.218 \\
191.785\end{array}$ & $\begin{array}{l}-148.218 \\
191.684\end{array}$ \\
\hline $100 \%$ Cash payment indicator & $\begin{array}{l}28.647 \\
33.277\end{array}$ & $\begin{array}{l}27.850 \\
33.136\end{array}$ & $\begin{array}{l}27.931 \\
33.243\end{array}$ \\
\hline $100 \%$ Stock payment indicator & $\begin{array}{l}-16.721 \\
43.625\end{array}$ & $\begin{array}{l}-16.912 \\
43.623\end{array}$ & $\begin{array}{l}-16.624 \\
43.572\end{array}$ \\
\hline Cash flow / assets & $\begin{array}{l}-40.881 \\
97.289\end{array}$ & $\begin{array}{l}-41.250 \\
95.339\end{array}$ & $\begin{array}{l}-46.380 \\
97.909\end{array}$ \\
\hline Transaction value / Acq market value & $\begin{array}{l}-53.451 \text { *** } \\
19.398\end{array}$ & $\begin{array}{l}-53.717^{* * * *} \\
19.596 \\
\end{array}$ & $\begin{array}{l}-52.917^{* * * *} \\
19.342\end{array}$ \\
\hline $\mathrm{N}$ & 4,697 & 4,697 & 4,696 \\
\hline Adj R-Sq & 0.05 & 0.05 & 0.05 \\
\hline Year fixed effects & Yes & Yes & Yes \\
\hline Industry fixed effects & Yes & Yes & Yes \\
\hline
\end{tabular}




\section{Table 9. Outside director departures and subsequent extreme negative stock returns}

The table shows results from logistic regressions of extreme negative stock returns following outside director departures. The analysis is based on 61,137 firm-years in the director departure dataset. The dependent variable is equal to one if in any of the 12 months following the proxy date or director departure date the monthly return is three standard deviations below the average monthly return over the past two years. Outside dir depart indicator is equal to one if there is at least one outside director departure. Surprise outside director departure (1) is an indicator variable which equals one if there is at least one departure of an outside director age 69 and below. Surprise outside director departure (2) is an indicator variable which equals one if there is at least one departure of an outside director whose survival function from the Cox proportional hazard model in Table 2, Column 1 is higher than 50\%, but the director nevertheless departs. Average monthly stock return is the average of monthly stock returns from the previous 12 months, ending in the month of the departure date or event date. Average stock return standard deviation is the average of the monthly standard deviation of daily stock returns. $\log ($ Market capitalization) is the natural logarithmic transformation of market capitalization measured at the date of director turnover, in millions of 2008 dollars. Average turnover is the average of monthly stock turnover, where turnover is defined as shares traded divided by shares outstanding. NYSE (Nasdaq) turnover is set to zero for all Nasdaq (NYSE and AMEX) firms. Standard errors clustered at the firm level are reported in italics. Intercepts are not reported. Marginal effects and their corresponding standard errors are provided. Statistical significance at the $1 \%, 5 \%$, and $10 \%$ level is indicated by $* * *, * *$, and $*$, respectively.

\begin{tabular}{llll}
\hline & $(1)$ & $(2)$ & $(3)$ \\
\hline Outside dir depart indicator & $0.005^{*}$ & & \\
Outside dir surprise depart (1) & 0.003 & & \\
& & $0.011^{* * *}$ & \\
Outside dir surprise depart (2) & & 0.003 & \\
& & & $0.009^{* * *}$ \\
Board size & & & 0.003 \\
& $-0.003^{* * *}$ & $-0.003^{* * *}$ & $-0.003^{* * *}$ \\
Proportion of outside directors & 0.000 & 0.000 & 0.000 \\
& 0.004 & 0.002 & 0.002 \\
Log (Market capitalization) & 0.007 & 0.007 & 0.007 \\
& $0.002^{* *}$ & $0.002^{* * *}$ & $0.002^{* * *}$ \\
Average monthly return & 0.001 & 0.001 & 0.001 \\
& $0.244^{* * *}$ & $0.245^{* * *}$ & $0.245^{* * *}$ \\
Average stock return standard deviation & 0.032 & 0.031 & 0.031 \\
& $-1.088^{* * * *}$ & $-1.114^{* * * *}$ & $-1.105^{* * *}$ \\
Average turnover (NYSE, AMEX) & 0.095 & 0.095 & 0.095 \\
& 0.009 & 0.007 & 0.008 \\
Average turnover (Nasdaq) & 0.034 & 0.034 & 0.034 \\
& $0.060^{* * *}$ & $0.058^{* * *}$ & $0.059^{* * *}$ \\
\hline Pseudo R-Sq & 0.013 & 0.013 & 0.013 \\
N & 0.06 & 0.06 & 0.06 \\
Year fixed effects & 60,460 & 60,460 & 60,441 \\
\hline
\end{tabular}

